mary tumour virus (which appears to be transmitted from one generation of mice to the next in the maternal milk, but only in suitable genetic strains). Work with tumour viruses came into its own in the fifties, particularly with the recognition of leukaemia viruses first in mice and then in other animals including cattle. The Nobel Committee said last week of Dr. Rous's work that "its real importance and bearing have only been comprehended in the last ten years".

Professor Huggins, who is 66 , has been singled out by the Nobel Committee for his study of endocrine influences on the prostate gland "which paved the way for the treatment of one of our most common species of cancer, the one most frequent in males, which until then had withstood all forms of treatment". In the late thirties, in experiments with dogs, Dr. Huggins established that the prostate is dependent on the male sex hormones (androgens) produced in the testicles. The effect of these on the prostate can be neutralized by female sex hormones, which can cause the gland to atrophy even when cancerous. Professor Huggins, who has been at Chicago since 1921, has been since 1951 director of the Ben May Laboratory for Cancer Research at the University of Chicago Hospital.

\section{Natural History Report}

THE British Museum (Natural History) - as it says-has broken with the sad precedent of recent years, and has published a report on its activities in the period 1963-65 (obtainable from the museum at 12s.6d.). The document will be valuable not merely as a record of events but as a statement of the problems which the museum is having to face in its attempt to meet the growing and ever-changing demand on its services.

Nearly 90 per cent of the budget is spent on research, and more than half of the 584 staff members are scientists. More than 50,000 scientists paid visits to the museum during 1963-65, usually because of the zoological and entomological collections. (The latter, with 18 million specimens, is still the largest in the world.) The museum continues to give advice prolifically, and during the period covered by the report it carried out a study of snails (Theba pirana) infesting the runways of a U.S. Navy air base in Morocco and helped British aircraft manufacturers to identify the remains of birds ingested by jet engines. During the same period, 27 major scientific expeditions were mounted by the museum itself and in conjunction with other organizations. The twelve weeks spent in Zambia and Tanzania collecting fossils from the Permian and Triassic rocks around Lake Malawi seem to have been particularly worthwhile. That expedition recovered 450 specimens, including from Zambia the remains of what must be the largest fossil amphibian so far-a skeleton $13 \mathrm{ft}$. long with a 4 -ft. skull. The taxonomic work at the museum has been given a biochemical flavour by the work seeking to establish accurate biochemical criteria for differentiating populations of snails and particularly those which act as hosts for the schistosome blood-flukes of man in Africa. It appears that the egg proteins are sensitive indicators of population differences, and that differences between the proteins can account for the existence of distinctive strains of parasites, each of them adapted to its own host population.

But change and growth make problems. The budget of the museum has increased from $£ 591,000$ in 1962-63 to $£ 816,000$ in $1965-66$, but the staff and the collections are increasingly cramped for space. The trustees, in the current report, recall that the need for more space has been recognized ever since 1961, when the Standing Committee on Museums and Galleries considered that an extra 140,000 sq. ft. was needed because "collections have for many years been overflowing into corridors, with some staff working in partitioned passages and odd corners". Expansion was also commended by the Taxonomy Committee of the Royal Society in 1963, and more staff has indeed materialized.

\section{Geophysics 1967}

THe purpose of the International Geophysical Calendar (see Table 1) is to provide a framework for international geophysical research. For observations which it is not possible or sensible to carry out daily, the Calendar suggests specific dates, and geophysicists can then make observations with reasonable confidence that similar, or related, observations are being carried out at the same time in different parts of the world.

Table 1. International Geophysical Calendar TABLE OF WORLD DAYS

\begin{tabular}{|c|c|c|c|c|c|c|c|}
\hline 1967 & RWD & PRWD & QWD & RGD & WGI & ECL & Meteors \\
\hline Jan. & $17,18,19$ & 18 & 一 & $4,11,18,25$ & - & - & $3-4$ \\
\hline Feb. & $14,15,16$ & 15 & 15 & $1,8,15,22$ & $13-26$ & - & - \\
\hline Mar. & $14,15,16$ & 15 & - & $1,8,15,22,29$ & - & 一 & - \\
\hline Apr. & $11,12,13$ & 12 & - & $5,12,19,26$ & - & - & 22 \\
\hline May & $9,10,11$ & 10 & 10 & $3,10,17,24,31$ & 8-21 & 9 & $4-6$ \\
\hline June & $13,14,15$ & 14. & 一 & $7,14,21,28$ & - & - & $6-10$ \\
\hline July & $18,19,20$ & 19 & 一 & $5,12,19,26$ & - & - & $28-30$ \\
\hline Aug. & $15,16,17$ & 16 & 16 & $2,9,16,23,30$ & $14-27$ & - & $10-14$ \\
\hline Sep. & $19,20,21$ & 20 & - & $6,13,20,27$ & - & - & - \\
\hline Oct. & $17,18,19$ & 18 & $一$ & $4,11,18,25$ & - & - & $20-21$ \\
\hline Nov. & $14,15,16$ & 15 & 15 & $1,8,15,22,29$ & $13-26$ & 2 & $16-17$ \\
\hline Dec. & $12,13,14$ & 13 & - & $6,13,20,27$ & - & - & $\begin{array}{l}12-14 \\
22-23\end{array}$ \\
\hline
\end{tabular}

In this way, more data are made available for Calendar dates than for other days in the year, and the amount of geophysical knowledge is concentrated, instead of being evenly spread. Regular World Days (RWD) are three consecutive days each month intended for observations which can only be made on about 10 per cent of the days in the year, and are particularly suitable for meteorological or geomagnetic observations. Priority Regular World Days (PRWD) are for work which can or needs to be done only once a month. Quarterly World Days (QWD) are four selected PRWDS, and are intended to be used for co-ordinating high altitude rocket experiments. Regular Geophysical Days (RGD) occur every Wednesday throughout the year, and are particularly intended for meteorological work. World Geophysical Intervals (WGI) are fourteen consecutive days in each season, intended for study of seasonal variations, and the timing of seasonal changes. Solar eclipse days are marked ECL, and meteor showers of special interest are also included in the Calendar.

\section{Geologists Hard Up}

THE Geological Society of London is facing up to a problem that has become increasingly urgent over the last few years-a widening gap between income and 